\title{
COLLECTIVE RIGHTS OF PERSONS ENGAGED IN GAINFUL EMPLOYMENT OUTSIDE THE EMPLOYMENT RELATIONSHIP - AN OUTLINE OF THE ISSUE ${ }^{1}$
}

\begin{abstract}
The main objective of the following study is to introduce readers to the issue of the 2nd National Scientific Conference in the series "Atypical Employment Relations" organized on 3 October 2019 by the Centre for Atypical Employment Relations of the University of Lodz. The consequence of extending the right of coalition to persons performing paid work outside the employment relationship was that they were guaranteed important collective rights, which until 1 January 2019 were reserved primarily for employees. The rights which Polish legislator ensured to non-employees include the right to equal treatment in employment due to membership in a trade union or performing trade union functions; the right to bargain with a view to the conclusion of collective agreement and other collective agreements; the right to bargain to resolve collective disputes and the right to organize strikes and other forms of protest, as well as the right to protect union activists. The author positively assesses the extension of collective rights to people engaged in gainful employment outside the employment relationship, noting a number of flaws and shortcomings of the analyzed norms. The manner of regulating this matter, through the mechanism of referring to the relevant provisions regulating the situation of employees, the statutory equalization of the scope of collective rights of non-employees with the situation of employees, the lack of criteria differentiating these rights, as well as the adopted model of trade union representation based on company trade unions, not taking into account the specific situation of people working for profit outside the employment relationship, are the reasons why the amendment to the trade union law is seen critically and requires further changes.
\end{abstract}

Keywords: right of coalition, persons engaged in gainful employment outside employment relationship, non-employees, collective employment law, trade union.

\section{UPRAWNIENIA ZBIOROWE OSÓB WYKONUJĄCYCH PRACE ZAROBKOWĄ POZA STOSUNKIEM PRACY - ZARYS PROBLEMATYKI}

Streszczenie. Głównym celem opracowania jest wprowadzenie czytelników w problematykę II Ogólnopolskiej Konferencji Naukowej z cyklu „Nietypowe stosunki zatrudnienia” zorganizowanej dnia 3 października 2019 r. przez Centrum Nietypowych Stosunków Zatrudnienia Uniwersytetu

\section{*University of Lodz, Department of Labour Law; tduraj@wpia.uni.lodz.pl}

${ }^{1}$ The article was prepared as part of a project financed by the National Science Centre in Poland pursuant to the decision number DEC-2018/29/B/HS5/02534. The project's registration number is: $2018 / 29 / \mathrm{B} / \mathrm{HS} 5 / 02534$. 
Łódzkiego. Konsekwencją rozszerzenia prawa koalicji na osoby wykonujące pracę zarobkową poza stosunkiem pracy było zagwarantowanie im ważnych uprawnień zbiorowych, które do 1 stycznia 2019 r. były zastrzeżone przede wszystkim dla pracowników. Polski ustawodawca zapewnił niepracownikom: prawo do równego traktowania $\mathrm{w}$ zatrudnieniu $\mathrm{z}$ uwagi na przynależność związkową lub pełnienie funkcji związkowych; prawo do rokowań mających na celu zawarcie układu zbiorowego pracy i innych porozumień zbiorowych; prawo do rokowań w celu rozwiązywania sporów zbiorowych oraz prawo do organizowania strajków i innych form protestu oraz prawo do ochrony działaczy związkowych. Autor pozytywnie oceniając przyznanie uprawnień zbiorowych osobom pracującym zarobkowo poza stosunkiem pracy, dostrzega szereg wad i mankamentów analizowanych unormowań. Sposób uregulowania tej materii, poprzez mechanizm odesłania do odpowiednich przepisów regulujących sytuację pracowników, ustawowe zrównanie zakresu uprawnień zbiorowych niepracowników z sytuacją pracowników, brak kryteriów różnicujących te uprawnienia, a także przyjęty model reprezentacji związkowej oparty na zakładowych organizacjach związkowych, nie uwzględniający szczególnej sytuacji osób pracujących zarobkowo poza stosunkiem pracy, każe krytycznie podchodzić do nowelizacji prawa związkowego, które wymaga dalszych zmian.

Słowa kluczowe: prawo koalicji, osoby pracujące zarobkowo poza stosunkiem pracy, niepracownicy, zbiorowe prawo zatrudnienia, związki zawodowe.

The following book is the summary of the 2nd National Scientific Conference in the series "Atypical Employment Relations" organized on 3 October 2019 by the Centre for Atypical Employment Relations at the Faculty of Law and Administration of the University of Lodz. The theme of the conference was Collective labour law or collective employment law? Protection of the rights and collective interests of persons engaged in gainful employment outside the employment relationship. The decision of the organisers on choosing such topic was influenced by the adoption on 5 July 2018 of the law amending the Trade Union Act and certain other laws (Journal of Acts 2018, item 1608). This act has been in force in Poland since 1 January 2019 and extends the right to form and join trade unions to persons engaged in gainful employment outside the employment relationship, including the self-employed if they do not employ other people for this type of work. This is a very important regulation that is a breakthrough in the collective employment relationship. Taking into account the great importance of the amendment to the trade union law, as well as the doubts and controversies in the legal doctrine and in practice arising from the extension of the right of coalition, the choice of the conference topic should be considered fully justified. The importance of this scientific event is raised by the fact that the conference was attended by many distinguished guests from the world of science, jurisprudence and practice, and the role of speakers and commentators was played by such eminent specialists in the field of collective labour law as Prof. Ludwik Florek (University of Warsaw); Prof. Zbigniew Hajn (University of Lodz); Prof. Jakub Stelina (University of Gdansk); Prof. Iwona Sierocka (University of Bialystok); Prof. Łukasz Pisarczyk (University of Warsaw); Prof. Artur Tomanek (University of Wroclaw); Prof. Monika Gładoch (The Cardinal Wyszyński University in 
Warsaw); Prof. Krzysztof Walczak (University of Warsaw); Dr Magdalena Rycak (The Lazarski University in Warsaw) and Dr Jakub Szmit (University of Gdansk). It was a great honour for me to be able to present in front of such a noble group a lecture entitled The rights of persons performing gainful employment outside the employment relationship in the light of collective labour law (employment) - selected problems. The importance, complexity, multithreading and topicality of the issues undertaken at the conference are confirmed by the set of articles that make up the publication that we are handing over to you. They concern fundamental issues such as: The concept of employer and the extension of the subjective (ratione personae) scope of collective labour law (prof. Zbigniew Hajn); The issue of representativeness in the lights of the amended Trade Unions Act (prof. Irena Sierocka); The right to strike and other forms of protest of persons performing gainful employment under civil law (prof. Artur Tomanek); Powers of trade union activists engaged in self-employment-assessment of Polish legislation (prof. Tomasz Duraj). In addition to the broad perspective of the matter under scrutiny provided by the articles: Open coalition law, necessity or threat? (dr Błażej Mądrzycki); Collective labour rights of self-employed persons on the example of Spain: is there any lesson for Poland? (dr Aneta Tyc); Come together now! New technologies and collective representation of platform workers (prof. Joanna Unterschütz), the post-conference publication also includes studies on specific issues relating to the functioning of collective employment law: Will 'yellow' unions disappear after the amendment to Act on trade unions? (dr Magdalena Rycak); The legal nature of remuneration for periods of release from the obligation to perform work for trade union activists (dr Małgorzata Mędrala); Whistleblower rights and protection in the workplace: The role of trade unions in Poland. Selected issues (dr Łucja Kobroń-Gąsiorowska); Staff representation rights related to the creation of employee capital plans - PPK (dr Marcin Krajewski).

A breakthrough moment for the revision of the Polish trade union law was the announcement of the judgement of 2 June 2015 (K 1/13, OTK 2015, No. 6, item 80 ), in which the Constitutional Tribunal found that Article 2(1) of the Trade Union Act of 23 May 1991 (i.e. Journal of Acts 2019, item 263 hereinafter: UZZ) in so far as it restricts the freedom to form and join trade unions of persons engaged in gainful employment not mentioned in that provision, is incompatible with Article 59(1) in connection with Article 12 of the Polish Constitution of 2 April 1997 (Journal of Acts 1997, No. 78, item 483 as amended), as well as international agreements binding Poland (more broadly: Grzebyk 2016, 199 and next; Duraj 2018, 129 and next). According to the Constitutional Tribunal, the defectiveness of the current statutory regulation resulted from its too narrowly defined subjective scope, which prevented the freedom of association in trade unions of a certain group of persons who were addressees of freedom, as referred to in Article 59(1) in connection with Article 12 of the Constitution. Article 59 of the Constitution 
guarantees the right of the coalition to all working people who have been granted such a right under international agreements ratified by Poland, to the extent established by those agreements, regardless of the basis of employment. It is granted to anyone who, while performing work, has specific economic or social interests directly related to professional activity, which require trade union protection. The basis for the adoption by the Constitutional Tribunal of a broad approach to the right of coalition was the examination of acts of international law, in particular the International Labour Organisation Convention No. 87 of 9 July 1948 on freedom of association and the protection of trade union rights ratified by Poland on 25 February 1957 (Journal of Acts 1958, No. 29, item 125). The act indicates that the essence of the right of coalition is that all working people can freely form trade union organisations, according to their will, without the need for the consent of state bodies. In accordance with Article 2 of ILO Convention No. 87, contractors (in the original version of the act: workers, travailleurs) and hiring entities, without any distinction, have the right, without prior authorisation, to set up organisations at their discretion and to join those organisations, subject to the necessary compliance with their statutes (more broadly: Grzebyk, Pisarczyk 2019, 83).

The Constitutional Tribunal, recognizing the unconstitutionality of the Polish Trade Union Act, introduced the constitutional concept of "employee" understood much broader than the one occurring in the provisions of the Labour Code (Article 2 and 22 of the Labour Code - law of 26 June 1974, i.e. Journal of Acts of 2020, item 1320 as amended - hereinafter referred to as KP). In the opinion of the Tribunal, the status of an employee as a constitutional subject of the freedom of association in trade unions - pursuant to Art. $59 \mathrm{sec} .1$ of the Polish Constitution - should be assessed through the prism of three basic criteria: performing paid work; remaining in a legal relationship (regardless of its type) with the entity for which the work is provided; and having professional interests related to the performance of work that can be protected in groups (see polemically: Świątkowski 2016, 11, 14; Musiała 2015; Kapusta 2016, 127 and next).

Taking into account the judgment of the Constitutional Tribunal of 2 June 2015, which recognized the unconstitutionality of the UZZ provisions as to the subjective scope of the of coalition, the Polish legislature decided to extend this right to persons performing gainful work outside the employment relationship. Pursuant to Art. 2 clause 1 in conjunction with art. 11 point $1 \mathrm{UZZ}$, the right to create and join trade unions is granted to persons who are engaged in paid work on a basis other than an employment relationship if they do not employ other persons for this type of work, irrespective of the basis of employment, and have rights and interests relating to the performance of work which may be represented and defended by the trade union. The decision of the Polish legislature to extend the right of coalition to persons engaged in gainful employment outside the employment relationship (including the self-employed) should be assessed 
positively. This solution offers a good opportunity to improve their legal situation, in particular their working conditions. From 1 January 2019, persons engaged in gainful employment outside the employment relationship may both join existing trade union organisations which bring together workers (mixed unions) and set up their own trade union organisations bringing together only non-employees. Following an amendment to trade union law, in accordance with Article 7 of the UZZ, trade unions are required, in respect of collective rights and interests, to represent all the aforementioned persons, irrespective of their trade union affiliation. On the other hand, in individual matters relating to the exercise of gainful employment, trade union organisations represent, in principle, the rights and interests of their members. In accordance with Article 26(1) of the UZZ, it is for trade union organisations to take a position on individual matters of persons engaged in gainful employment in the field of the performance of that work. Furthermore, granting persons working outside the employment relationship the right of the coalition strengthens the effectiveness of the control of compliance by the entity organizing the work of those persons with the rules governing the conditions under which they are to provide the services assigned to them. Pursuant to Article 8 of the UZZ, in accordance with the principles laid down in this Law and in separate laws, trade unions shall monitor compliance with the rules on the interests of those persons and the interests of their families. In particular, this concerns control over compliance at work with the rules and rules on health and safety at work, to which the trade union organisations are required under Article 26(3) of the UZZ. Following the amendment of trade union law, trade union organisations representing persons working outside the employment relationship are also obliged to defend their dignity, rights and material and moral interests, both collective and individual (Article 4 UZZ). Pursuant to Article 5 of the UZZ, those persons, through trade unions, have the right to represent their interests internationally.

A significant disadvantage of the amendment to Trade Union Act is the imprecise personal scope of the right of coalition defined in the UZZ resulting from the unclear definition of persons engaged in gainful employment outside the employment relationship included in Article $1^{1}(1)$ of the UZZ. In particular, the reservations concern the condition that there are rights and interests relating to the performance of work which may be represented and defended by the trade union. The doctrine of labour law (see, for example, Stelina 2018,26) raises the difficult verifiability of this criterion, given that everyone who provides work (services) most often has some interest in the economic conditions of the performance of work (living or social). It is easy to circumvent this condition by skilfully defining in the statutes the objectives and tasks of the trade union concerned. De lege lata there are also no instruments to effectively verify whether a group of entities forming a trade union organisation has rights and interests relating to the performance of work 
which can be represented and defended by a trade union. There is also no entity to verify this. Neither the hiring entity with which the trade union is formed nor the court at the registration stage of the trade union has such capacity.

The aforementioned shortcoming raises legitimate doubts about the precise definition of persons engaged in gainful employment outside the employment relationship who can enjoy the privileges of collective labour law immanently connected with the right of coalition. It must be realised that the consequence of granting non-employees the right to join trade union organisations is to guarantee them additional collective rights. In that regard, Polish legislature granted persons engaged in gainful employment outside the employment relationship the right to equal treatment in employment. Expressis verbis any unequal treatment of the self-employed persons on grounds of their membership or remaining outside the trade union or performing any trade union functions resulting in particular in the refusal to establish or terminate a legal relationship, the unfavourable formation of remuneration for gainful employment or other conditions of employment, being overlooked for a promotion, being refused other benefits relating to gainful employment, as well as being overlooked for any professional development training, shall be prohibited, unless the hiring entity proves that it was guided by objective reasons. Moreover, Polish legislature introduces a mechanism similar to the one applied in case of regular employees, according to which any provisions of civil law contracts under which non-employees provide their services infringing the principle of equal treatment in employment shall become null and void. In such a case, the relevant legal provisions governing the legal relationship between those persons and the hiring entity shall apply instead of such provisions and, in the absence of such provisions, those provisions shall be replaced by appropriate non-discriminatory provisions (Article $3 \mathrm{UZZ}$ ). This is therefore a far-reaching interference by the legislature in the principle of freedom of contract in force under Article $353^{1}$ of the Civil Code (Act of 23 April 1964, i.e. Journal of Acts 2020, item 1740 as amended - hereinafter $\mathrm{KC}$ ), which in this case must nevertheless be regarded as fully justified. In the event of a breach by the hiring entity the principles of equal treatment of persons engaged in gainful employment outside the employment relationship, the right to compensation of not less than the minimum wage, determined on the basis of separate provisions, shall be guaranteed. In this respect, Polish legislature, unfortunately, by taking 'shortcuts', refers to the proper application of the provisions of the Labour Code. On the other hand, the solution that should be positively assessed is the one according to which the provisions of the Act of 17 November 1964 - Code of Civil Procedure on Labour Law Proceedings (i.e. Journal of Laws of 2020, item 1575, as amended - hereinafter referred to as the KPC) apply mutatis mutandis to proceedings concerning infringement of the prohibition of unequal treatment in employment on grounds of membership of a trade union or due to the exercise of a trade union function. Since the court 
with jurisdiction to hear these cases is the labour court, it will undoubtedly make it easier for non-employees to assert their claims, especially since, as in the case of employees, the burden of proof is passed onto the hiring entity. A person engaged in gainful employment outside the employment relationship must merely establish before the court the fact of unequal treatment in employment, and then the hiring entity will have to demonstrate that, by differentiating the situation of the employees, he was guided by objective reasons.

An important change introduced by the legislature from 1 January 2019 is to guarantee for the people engaged in gainful employment outside the employment relationship the right to conclude collective labour agreements and other collective agreements that will be dedicated exclusively to these people. Until then, nonemployees could only benefit from collective agreements which had previously been concluded for the employees of the entity organising their work. According to the previous wording of Art. $239 \S 2$ of the Labour Code, the agreement could cover persons performing work on a basis other than an employment relationship. The amendment to the trade union law opened up to people who perform paid work outside the employment relationship, as well as trade union organisations bringing them together, the possibility of conducting negotiations and concluding collective agreements which will set certain minimum safeguard standards in respect of all non-employees falling within the scope of the agreement. This is important as they are not covered by such statutory guarantees as employees. Due to the principle of freedom of contract in civil law (Article $353^{1}$ of the Civil Code) and the low negotiating potential of people working for profit outside the employment relationship, it often occurs that the employing entity unilaterally imposes unfavourable contract conditions on them, and the equality of the parties in this case is only apparent. The amendment of trade union law in this area therefore gives non-employees a great opportunity to strengthen their protection on an individual level, in particular as regards: remuneration and other benefits related to the services they provide, protection of life and health, working time and organisation of work, annual and parental leaves and other paid time off from work or protection of the sustainability of employment. Thanks to these solutions, persons working outside the employment relationship will be able to have a real impact on the formation of the company's labour law applicable to the entrepreneur with whom they are bound by a civil law contract. A significant drawback of the regulations analysed here is the way in which they are introduced for people engaged in gainful employment outside the employment relationship through the mechanism of appropriate application of regulations concerning employees. Pursuant to Art. 21 UZZ, the provisions of section XI of the Act - The Labour Code shall apply accordingly to persons, other than employees, engaged in gainful employment and to their employers, as well as to organisations representing them.

The amendment to trade union law guaranteed persons working outside the employment relationship the right to participate in the resolution of collective 
labour disputes. Until 1 January 2019, non-employees were, in principle, not able to organise strikes and other forms of protest to resolve collective disputes arising from their employment. The amendment granted them the right, through trade unions, to enter into a collective dispute with the hiring entity in order to protect their rights and collective interests on the same basis as workers. Pursuant to Article 6 of the Law of 23 May 1991 on the resolution of collective disputes (i.e. Journal of Acts 2020, item 123, hereinafter: URSZ), the provisions of that act, which refers to employees, shall apply mutatis mutandi to persons engaged in gainful employment. This means that de lege lata non-employees are guaranteed the right to formulate, through the trade unions representing them, demands aimed at satisfying their collective interests and to take legal forms of resolving collective disputes, in particular the right to co-decide on organizing a strike and the right to take active participation in it, including the ability to conclude poststrike agreements. Under Art. 1 URSZ, collective disputes may concern working conditions, pay or social benefits as well as the trade union rights and freedoms of people engaged in gainful employment outside the employment relationship. The interpretation doubts arising from the application of Art. 6 of the URSZ are more broadly analysed by prof. Artur Tomanek in his article which you can find in this post-conference publication.

Granting persons enaged in gainful employment outside the employment relationship the right of coalition means in consequence that they have the ability to function in trade union structures. This, in consequence, means that the Polish legislature guarantees trade union activists (having a non-employee status) the right to equal treatment in the course of their trade union function; the right to paid time off from work, both on an ad hoc basis (for the purpose of carrying out current activities resulting from their trade union function) and permanently; as well as the protection of the sustainability of civil law contracts constituting the legal basis for the services provided. In accordance with Article 32(1) UZZ, the hiring entity, without the consent of the management board of the enterprise trade union organization, may not dissolve or terminate the legal relationship with a non-employee designated by the resolution of the management board who is a member of a given enterprise trade union, authorized to represent this organization before the employer, and may not unilaterally change the working conditions or remuneration to the detriment of this person, with the exception of the declaration of bankruptcy or liquidation of the employer, and also if it is permitted by separate regulations. If the hiring entity breaches the above protection, a trade union activist employed outside the employment relationship has the right, irrespective of the amount of the damage suffered, to compensation in the amount equal to the 6-month remuneration to which that person was entitled in the last period of employment, and if the remuneration of that person is not paid on a monthly basis - in the amount equal to 6 times the average monthly salary in the national economy in the previous year, announced by the President of the 
Central Statistical Office. Moreover, this person may claim damages or redress exceeding the amount of such compensation (Art. $32\left(1^{3}\right) \mathrm{UZZ}$ ). I believe that the scope of powers granted to union activists employed outside the employment relationship is too far-reaching. The legislator, by equalizing their legal situation with that of trade unionists having an employee status, does not take into account the specificity of people working for profit under civil law contracts. De lege lata, the scope of rights guaranteed to trade union activists employed outside the employment relationship constitutes an excessive and unjustified interference with the fundamental principle of freedom of contract on the basis of civil law employment relations. My doubts and the assessment of the legal regulation of the rights of trade union activists engaged in gainful employment outside the employment relationship have been presented by me on the example of selfemployed persons in a separate article in this post-conference publication.

A serious threat to the effectiveness of the solutions adopted after the amendment to the trade union law regarding the collective rights of persons engaged in gainful employment outside the employment relationship is the maintenance of the model based on company trade unions, which are granted the most far-reaching competences in the field of representation and defense of the rights as well as professional and social interests of working people. This is a large inconsistency on the part of the Polish legislature, because this model is adapted only to employee employment relationships, where we are dealing with voluntarily subordinated work for one employer. The special situation of people who perform paid work outside the employment relationship (especially on the basis of civil law contracts) is that they are not bound by one (specific) workplace (usually there are several jobs). This requires a reconstruction of the current model of trade union representation, which is currently based on company trade unions for the purpose of the statutory strengthening of supra-company trade union structures, which take into account the specificity of non-employee employment relations much better.

Another aspect that leaves much to be desired is the way in which Polish legislature has regulated the collective rights of persons working outside the employment relationship. By adopting a "shortcut" Polish legislature does not introduce separate regulations taking into account the specificities of persons working outside the employment relationship and uses a dubious mechanism of referring to the relevant provisions regarding the situation of employees. In this way, the Polish legislator regulates both the right to equal treatment in employment on the basis of trade union membership or the performance of trade union functions in the scope of claims, and the right to bargain for the resolution of collective disputes, including, in particular, the right to organise strikes. Such a way of regulating this issue raises many interpretative problems, making the legal situation of people engaged in gainful employment outside the employment relationship unclear and uncertain in the context of the practical application of the above-mentioned 
collective rights. This can be clearly seen in the appropriate application of the provisions of the URSZ to non-employees. There are numerous doubts brought by the regulation as to whether these people are granted all the rights guaranteed to employees in the field of settling collective labour disputes and, for example, what is their responsibility for participating in an illegal strike? (see more broadly Duraj 2020, 73-75). While I disapprove of the above-discussed method of regulating the collective rights of people working outside the employment relationship through the mechanism of referring to the relevant provisions regulating the situation of employees, I believe that the legislator should attempt to create separate regulations in this respect (modelled on the provisions of the labour law), which will be adjusted to to the specific conditions under which these persons provide services to the employing entity. This would eliminate a number of interpretative doubts that arise de lege lata under existing trade union law.

Finally, it should be noted that the way in which the Polish legislature has regulated the guarantees under coalition rights regarding collective labour law for persons engaged in gainful employment outside the employment relationship leads in in many cases to equality (significant approximation) of the level of their protection with that of employees. This is reflected in: the right to equal treatment in employment on grounds of trade union membership or the exercise of trade union functions; the right to bargain with a view to the conclusion of a collective labour agreement and other collective agreements; the right to bargain for the particular purpose of the resolution of collective disputes, as well as the right to organise strikes and other forms of protest and the right to protect trade union activists. While this tendency does not raise any objections with regard to the exercise of the right to equal treatment or the right to conclude collective labour agreements and other collective agreements, it is very questionable with regard to the rights of trade union activists (especially with regard to paid leaves from work and the requirement of consent to terminate a civil law contract), or the right to strike or other forms of protest. It is a mistake to equate the level of collective entitlements of people engaged in gainful employment outside the employment relationship with the entitlements of employees. Firstly, there is no justification for this in the international standards in force in Poland. Secondly, such an approach of the Polish legislature does not sufficiently take into account the differences resulting from non-standard forms of employment. The scope of collective rights guaranteed de lege lata to persons engaged in gainful employment outside the employment relationship (primarily on the basis of civil law contracts) constitutes an excessive and unjustified interference with the fundamental principle of freedom of contract in terms of civil law employment relations. This regulation does not take into account the specificity of non-employees, who most often do not have such a strong legal relationship with the hiring entity as employees.

Another serious drawback of the regulation at issue is also the fact that the Polish legislature does not differentiate in any way the scope of collective 
rights guaranteed to people working for profit outside the employment relationship, ensuring the same level of protection to all, regardless of their actual and legal situation. It seems that in this area de lege ferenda the scope of these rights should be diversified, for example by referring to the criterion of economic dependence on the hiring entity for whom work is provided outside the employment relationship. This means that the broadest range of privileges (the most similar to the situation of employees) should apply only to those nonemployees whose income is wholly or predominantly derived from the employing entity where a given trade union organization representing their interests operates. Such a criterion for the application of rights (also of a collective nature) to nonemployees is found in the legislations of certain European countries, which I am more broadly describing in the second article in this publication (see also the article by Dr Aneta Tyc). The criterion of hourly dependence on the hiring entity, as proposed in the draft of Individual Labour Code of $2018^{2}$ is also worth considering.

Encouraging you once again to read the publication summarizing 2nd National Scientific Conference in the series "Atypical Employment Relations", I would like to positively assess the decision of the Polish legislature extending the right of coalition to persons performing gainful employment outside the employment relationship. As a consequence of this move, self-employed persons were granted additional collective rights from 1 January 2019, which until now were reserved primarily to employees. This solution paves the way for non-workers to improve their legal situation (to strengthen their protection on an individual basis), in particular working conditions, by the possibility of raising protection standards through systemic regulation. This is so important that persons who work for a profit outside the employment relationship are generally not covered by the legislature, like workers, by a minimum level of protection. This is even more important as the people working outside the employment relationship are generally not covered by the legislature, like employees, with the minimum scope of protection. Unfortunately, the way this matter is regulated through the mechanism of reference to the relevant provisions regulating the situation of employees, the statutory equalization of the scope of collective rights of nonemployees with the situation of employees, the lack of criteria differentiating these rights, as well as the adopted model of trade union representation based on company trade unions, not taking into account the specific situation of people engaged in gainful employment outside the employment relationship, contribute to the critical perception of the amendment to the trade union law, which requires further changes. The shortcomings of this regulation are also confirmed by the

${ }^{2}$ Pursuant to Art. $177 \S 1$ of this project, an economically dependent self-employed person is a person who provides services performing them independently for a specific entrepreneur or organizational unit that is not an entrepreneur or a farm (contractor), directly, on average for at least 21 hours per week, for a period of at least 182 days. 
practice of implementing these provisions. After one and a half years of the new union law being in force, this group of people shows little interest in the right of coalition. Even in industries where civil-law employment dominates and there are strong union structures (e.g. health service), no actions aimed at creating nonemployee trade unions have been observed, and joining the existing labour unions for people engaged in gainful employment outside employment relationship is also rare. Answering the question posed to the conference participants in its title, there is no doubt that the amendment to the trade union law of July 5, 2018 opens a new chapter in the history of collective labour relations regulations, providing clear grounds for formulating the thesis on de lege lata of collective employment law (see also Baran 2018, 4).

\section{BIBLIOGRAPHY}

Baran, Krzysztof Wojciech. 2018. "O zakresie prawa koalicji w związkach zawodowych po nowelizacji prawa związkowego z 5 lipca 2018 r.”. Praca i Zabezpieczenie Spoleczne 9: $2-4$.

Duraj, Tomasz. 2018. "Prawo koalicji osób pracujących na własny rachunek". In Zbiorowe prawo zatrudnienia. Edited by Jakub Stelina, Jakub Szmit. Warszawa: Wolters Kluwer Polska.

Duraj, Tomasz. 2020. "Prawo koalicji osób pracujących zarobkowo na własny rachunek po nowelizacji prawa związkowego - szanse i zagrożenia”. Studia z Zakresu Prawa Pracy i Polityki Spolecznej 27(2): 67-77.

Grzebyk, Piotr. 2016. "Glosa do wyroku TK z dnia 2 czerwca 2015 r.”. Przeglad Sadowy 11: 199206.

Grzebyk, Piotr. Łukasz Pisarczyk. 2019. "Krajobraz po reformie. Zbiorowa reprezentacja praw i interesów zatrudnionych niebędących pracownikami”. Praca i Zabezpieczenie Społeczne 1: $81-98$.

Kapusta, Piotr. 2016. “Glosa do wyroku TK z dnia 2 czerwca 2015 r., K 1/13”. Przegląd Sejmowy 5: $123-131$.

Musiała, Anna. 2015. "Glosa do wyroku TK z dnia 2 czerwca 2015 r., K 1/13”. LEX/el.

Stelina, Jakub. 2018. "Zbiorowe prawo zatrudnienia - podstawowe założenia teoretyczne". In Zbiorowe prawo zatrudnienia. Edited by Jakub Stelina, Jakub Szmit. 13-32. Warszawa: Wolters Kluwer Polska.

Świątkowski, Andrzej Marian. 2016. "Konstytucyjna koncepcja pracownika". Monitor Prawa Pracy 1: 8-14. 